\title{
Utilization of plant associated rhizobacteria to improve plant nutrition and protection: a cost effective and ecofriendly strategy
}

\author{
F. Y. Hafeez \& M. N. Hassan \\ Department of Biosciences, COMSATS Institute of Information Technology, \\ Islamabad, Pakistan
}

\begin{abstract}
Plant associated bacteria are beneficial microbes which inhabit various parts of plants such as rhizosphere, endosphere and polysphere. These small little wonders improve plant health either directly by providing nutrients or indirectly by suppressing disease causing pathogens. We isolated more than 1000 rhizobacteria from the rhizosphere and endosphere of various field crops and screened for biofertilizer and biopesticide characteristics. About 100 isolates were selected on the basis of best $\mathrm{N}$-fixation (3624 nmole $\mathrm{C}_{2} \mathrm{H}_{4} / \mathrm{mg}$ protein $/ \mathrm{h}$ ), P-solubilization $(320 \mu \mathrm{g} / \mathrm{mL})$, Silicate solubilization (35 mm zone), Indole acetic acid production $(62 \mu \mathrm{g} / \mathrm{mL})$, and in vivo biocontrol activity (30-60\%) under field conditions. These effective PGPR belonged to different genera such as Acetobacter, Pseudomonas, Azospirillum, Rhizobium, Azotobacter, Bacillus, Enterobacter, Aeromonas, Burkholderia and Serratia as identified by $16 \mathrm{~S}$ rDNA. Biocontrol activity of the antagonistic strains was found to be associated with the production of siderophores, antibiotics such as surfactin, pyoluteorin and hydrolytic enzymes like protease, glucanase and chitinase. The potent strains were preserved at Pakistan Collection of Microbial Cells (PCMC). The some efficient strains capable to solubilize phosphorus and survive in humic acid with a population of $10^{7}-10^{8} \mathrm{CFU} \mathrm{g}^{-1}$ until six months have been formulated as biofertilizers with the trade name Humiphos ${ }^{\mathrm{TM}}$ and Biophos ${ }^{\mathrm{TM}}$ in collaboration with Auriga Chemical Enterprises, Lahore, Pakistan. These biofertilizers saved 50\% chemical phosphatic fertilizer and increased the yield up to $10-20 \%$ of different field crops such as wheat, rice, potato, cotton, maize and vegetables. The development of liquid formulation of
\end{abstract}


these bioinoculants/biopesticide is in progress. Utilization of bioinoculants /biopesticide will facilitate the production of organic food.

Keywords: PGPR, diazotrophs, macronutrients, micronutrients, pathogens, biopesticide, Bio power, Humiphos, Biophos, commercialisation.

\section{Introduction}

Nutrients and pathogens are the major stresses that limit the plant growth. Among macronutrients, nitrogen, phosphorus and potassium are the most important nutrients. Extensive agricultural practices have depleted the nutrient level of soil and deteriorated its texture. According to the prevailing farming practices, chemical nitrogen and phosphatic fertilizer are applied to fulfil the nutritional requirements of plant. Moreover, Pakistani soils are mostly alkaline in nature and phosphorous exists in an insoluble form as calcium phosphates in the soil. In acidic soils, most of the insoluble phosphorous occurs as phosphates of iron and calcium which are insoluble and thus a great proportion of phosphate natural or added in the form of fertilizer is fixed in the soil and only a limited amount becomes available to the plants. Similarly, frequent use of pesticides has not only resulted in the emergence of resistant strains, but has caused several health and environment hazards. Hence, there is a dire need to develop an alternative strategy to enhance the fertilizer utilization protection of the plants from devastating pathogens.

Plant growth promoting rhizobacteria (PGPR) can play a significant role here by conversion of phosphorous into such a form that can be utilized by the plants. In addition to this they can improve the soil fertility and plant growth directly by nitrogen fixation, indole acetic acid production, silicate, zinc and potash mobilization and indirectly by the suppression of phytopathogens via the production of hydrolytic enzymes, siderophores, antibiotics and induced systemic resistance.

\section{PGPR and macronutrients}

\subsection{Nitrogen}

PGPR can fix atmospheric nitrogen either associating with legumes or non legume crops. These PGPR belong to different genera such as Acetobacter, Pseudomonas, Azospirillum, Rhizobium, Frankia, Azotobacter, Bacillus, Enterobacter, Aeromonas, Burkholderia and Serratia. Nitrogen fixation ability of these rhizobacteria is generally conferred by the nitrogenase enzyme encoded by nif gene. A large number of nitrogen fixers from legumes and non legumes have been isolated and characterized in our laboratories. A few strains are described in Table 1.

\subsection{Phosphorous s and phytohormones}

Phosphorous is the second major nutrient which is essential for crops. During a survey in Pakistan, it was found that in unproductive lands 85-95 ppm while in 
Table 1: Diazotrophs with different nitrogen fixing ability.

\begin{tabular}{|c|c|c|}
\hline Diazotrophs & $\begin{array}{c}\text { ARA * } \\
\text { nmole } \mathrm{C}_{2} \mathrm{H}_{4} \\
\text { /mg protein } / \mathrm{h}\end{array}$ & Reference \\
\hline Pseudomonas sp.Z2 & 1523 & Yasmin [1] \\
\hline $\begin{array}{c}\text { Bacillus } \text { sp. } \mathrm{F} 6 \\
\text { Azotobacter } \mathrm{sp} \\
\text { Z3-3 }\end{array}$ & 3624 & Naureen et al. [2] \\
\hline Frankia sp. & 90.8 & Yasmin et al. [3] \\
\hline $\begin{array}{c}\text { (Brady)Rhizobium } \\
\text { spp. }\end{array}$ & $58-121^{* *}$ & Hafeez et al. [4] \\
\hline
\end{tabular}

*Acetylene reduction assay; ** $\mu$ mole $\mathrm{C}_{2} \mathrm{H}_{4} / \mathrm{g}$ nodule dry wt. $/ \mathrm{h}$.

cultivated land 1200-1400 ppm phosphorous is present in soil but in fixed form. If a portion of this fixed phosphorous is solubilized by some source, the entire requirement of phosphorous can be fulfilled. In our experiments, few strains were found to be effective in solubilization of phosphorus by the production of various kinds of organic acids. The variable potential of PGPR with respect to the solubilization of phosphorous and production of phytohormones is given in Table 2.

Table 2: Phosphorous solubilization and phytohormones production of by the plant associated rhizobacteria.

\begin{tabular}{|c|c|c|c|}
\hline PGPR & $\begin{array}{c}\mathbf{P}- \\
\text { solubilization } \\
\mu \mathrm{g} / \mathrm{mL}\end{array}$ & $\begin{array}{l}\text { Production of } \\
\text { IAA**** }\end{array}$ & References \\
\hline Serratia spp*. & $97-112$ & $20-25$ & This study \\
\hline $\begin{array}{l}\text { Rhizobium } \\
\text { spp. }\end{array}$ & 204 & $3-16$ & Hassan [6] \\
\hline Bacillus sp & 77 & 17 & Yasmin [1] \\
\hline $\begin{array}{c}\text { Agrobacterium } \\
\text { sp.Ca-18 }\end{array}$ & 63.3 & 35 & $\begin{array}{c}\text { Hameed et al. } \\
{[7]}\end{array}$ \\
\hline $\begin{array}{l}\text { Pseudomonas } \\
\text { sp. Z5 }\end{array}$ & 95 & 1.2 & Yasmin [1] \\
\hline $\begin{array}{c}\text { Pseudomonas } \\
\text { sp Z2-7 }\end{array}$ & 310 & 62 & $\begin{array}{c}\text { Yasmin et al. } \\
\text { [3] }\end{array}$ \\
\hline
\end{tabular}

ND: Not detected; *The serratia spp also produce Gibrellic acid 36-46 $\mu \mathrm{g} \mathrm{mL}^{-1}$; **Phosphorous was quantified spectrophotometrically, ***IAA= Indole acetic acid. 


\subsection{Potash}

Potassium is a fundamentally important macronutrient in plants and animals. Recent studies have proved that potassium plays an important role in plant growth and is directly involved in the increase in plant height, fresh weight; herbage and oil yield. Potash deficiency results in chlorisis (loss of green colour) along the leaf margins. In severe cases, the leaf turns yellow and eventually falls off. Potash deficiency also affects plant growth and canopy photosynthesis process. Potassium solubilizing bacteria (KSB) such as Bacillus mucilagenosus and Bacillus edaphicus are examples of microorganisms that can be used to mobilize potassium in soil as KSB are able to solubilize insoluble potassium through the production and secretion of organic acids. We have recently focused on KSB for incorporation into bioformulations.

\section{PGPR and micronutrients}

\subsection{Zinc solubilization}

Zinc is an essential micronutrient which plants need to complete their life cycle and give maximum yield. It acts as co factor of numerous enzymes involved in different metabolic pathways. Most of the soils are deficient in zinc throughout the world. Hence, the supply of zinc in zinc deficient soils is necessary for obtaining optimum crop yield. In general practices, zinc is applied to the crops in the form of chemical fertilizers such as zinc sulfate etc. A large portion of applied zinc is also converted into an insoluble form due to a series of chemical reactions occurring in the soil. Therefore, solubilization of zinc by rhizobacteria is an alternative strategy to solve the problem of zinc availability to the plants. The bacterial strains capable of solubilizing zinc and promoting plant growth are listed in Table 3.

Table 3: $\quad$ Solubilization of zinc by the plant associated rhizobacteria.

\begin{tabular}{|c|c|c|c|}
\hline \multirow[t]{2}{*}{ PGPR } & \multicolumn{2}{|c|}{ Zn-solubilization $\left(\mu \mathrm{gmL}^{-1}\right)$} & \multirow[t]{2}{*}{ References } \\
\hline & $\mu \mathrm{g} \mathrm{mL} \mathbf{~}^{-{ }^{*}}$ & Mm** & \\
\hline Serratia $\mathrm{sp}$ & $73-84$ & $14-60$ & $\begin{array}{c}\text { Unpublished } \\
\text { data }\end{array}$ \\
\hline $\begin{array}{l}\text { Pseudomonas } \\
\text { sp. Z5 }\end{array}$ & ND & 2.0 & Yasmin [1] \\
\hline $\mathrm{Z} 2-7$ & ND & 27 & Ahmad [8] \\
\hline MA-1 & ND & 17 & Ahmad [8] \\
\hline NR-2 & ND & 32 & $\begin{array}{c}\text { Unpublished } \\
\text { data }\end{array}$ \\
\hline
\end{tabular}

ND: Not detected. *Quantified by atomic absorption spectrophotometer

**diameter of solubilization zone of different ores such as, zinc oxide, zinc sulphide, zinc carbonate and zinc phosphate. 


\subsection{Silicate mobilization}

Silicon, ( $\mathrm{Si}$ ) is the second most abundant element present on the earth's crust next to oxygen. Although silicon is not considered an essential plant nutrient yet it has been observed that soluble Si enhances the growth, development and yield of many plants. Moreover, it has been reported to decrease the incidence of many fungal diseases in different pathosystems. Despite its abundance in the earth's crust it is mostly present in insoluble forms that cannot be readily absorbed by plant roots. Silicate solubilizing bacteria (SSB) can play an efficient role here by solubilizing insoluble forms of silicates hence increasing soil fertility and enhancing plant defence mechanisms. In an initial study, we have isolated silicate solubilizing bacteria from the arid region of Pakistan with a mobilization zone of 5-25 mm diameter on silicate agar plates.

\section{PGPR and pathogens}

Biological control manifested by PGPR is a well documented area of research. Use of these biocontrol agents has had a worldwide increase during the past two decades. The largest percentage of the biopesticide has been used by North America i.e. $44 \%$ of the market share followed by the EU and Oceania with $20 \%$ each and about 6\% in Asia and India. Although biopesticide growth is projected at $10 \%$ annually, it is highly variable among the regions constrained by factors such as regulatory hurdles, public and political attitudes, and limitations for market expansion. Many rhizobacterial strains isolated in our lab can antagonize a wide range of phytopathogens such as Rhizoctonia solani, Magnaporthae grisae, Fusarium moniliformae, Altarnaria solani, Macrophomina phaseolina and Botrytis cinerea, Colletotrichum falcatum, etc. In addition to the inhibition of fungal pathogens some of these bacterial strains can inhibit plant pathogenic nematodes and bacteria as well, thus depicting their strong candidature for biopesticide production. Characteristics of a few of these biocontrol agents are shown in Table 4.

\section{Bio formulation of PGPR}

The selection of carrier material is a crucial step to formulate the PGPR. In our studies, initially, we used filter mud which is the byproduct of the sugarcane industry to pellet the seeds. Bacterial strains showed good survival in this carrier medium and were recommended for seed pelleting for legumes and root dip for rice. Currently, ammonium humate was used as carrier material which has numerous advantages over the press mud. In addition to carrying strains, humate has itself positive effects on soil such as, increase of organic matter, improvement of porosity and soil texture and is broadcasted like chemical fertilizers at the time of sowing. Survival of phosphate solubilizing bacteria was tested in humate. The strains capable of maintaining a population of up to $10^{7}$ CFU $\mathrm{g}^{-1}$ of humate were selected as an active ingredient of phosphatic biofertilizer. 
Table 4: $\quad$ PGPR controlling pathogens causing various diseases.

\begin{tabular}{|c|c|c|c|c|}
\hline PGPR & $\begin{array}{c}\text { Possible } \\
\text { mechanism }\end{array}$ & Disease & $\begin{array}{l}\text { Sensitive } \\
\text { pathogen }\end{array}$ & References \\
\hline $\begin{array}{l}\text { Pseudomonas } \\
\text { putida } \text { NH-50 }\end{array}$ & Pyoluteorin & $\begin{array}{c}\text { Sugarcane red } \\
\text { rot }\end{array}$ & $\begin{array}{c}\text { Colletotrichum } \\
\text { falcatum }\end{array}$ & $\begin{array}{c}\text { Hassan et al. } \\
\text { [9] }\end{array}$ \\
\hline $\begin{array}{c}\text { Bacillus subtilis } \\
\text { NH-100 }\end{array}$ & Surfactin & $\begin{array}{c}\text { Sugarcane red } \\
\text { rot }\end{array}$ & \begin{tabular}{|c|}
$\begin{array}{c}\text { Colletotrichum } \\
\text { falcatum }\end{array}$ \\
\end{tabular} & $\begin{array}{c}\text { Hassan et al. } \\
\text { [10] }\end{array}$ \\
\hline $\begin{array}{c}\text { Burkholderia } \\
\text { xenovorans }\end{array}$ & Siderophores & Rice blast & $\begin{array}{c}\text { Magnaporthe } \\
\text { grisea }\end{array}$ & $\begin{array}{c}\text { Naureen et al. } \\
{[11]}\end{array}$ \\
\hline $\begin{array}{l}\text { Enterobacter } s p \\
\text { B41 strain SPR7 }\end{array}$ & $\begin{array}{l}\text { Volatile and } \\
\text { diffusible } \\
\text { antibiotics, }\end{array}$ & $\begin{array}{l}\text { Rice sheath } \\
\text { blight }\end{array}$ & $\begin{array}{c}\text { Rhizoctonia } \\
\text { solani, }\end{array}$ & $\begin{array}{c}\text { Naureen et al. } \\
\text { [12] }\end{array}$ \\
\hline $\begin{array}{l}\text { Pseudomonas sp } \\
\text { sts3 }\end{array}$ & $\begin{array}{c}\text { HCN, } \\
\text { Siderophores }\end{array}$ & $\begin{array}{l}\text { Potato Black } \\
\text { scurf }\end{array}$ & & $\begin{array}{l}\text { Tariq et al. } \\
\text { [13] }\end{array}$ \\
\hline $\begin{array}{c}\text { Pseudomonas } \\
\text { fluorescence Mst- } \\
8.2 \\
\end{array}$ & & & & $\begin{array}{l}\text { Gull et al. } \\
\text { [14] }\end{array}$ \\
\hline $\begin{array}{c}\text { Serratia } \\
\text { proteamaculans }\end{array}$ & Chitinase & ------ & Fusarium $\mathrm{sp}$ & $\begin{array}{c}\text { Mehmood et } \\
\text { al. }[15]\end{array}$ \\
\hline $18 \mathrm{~A} 1$ & & & & \\
\hline $\begin{array}{c}\text { Bacillus subtilis } \\
\text { SPS2, }\end{array}$ & Proteases & $\begin{array}{c}\text { Tomato root } \\
\text { knot }\end{array}$ & Melodogyne sp & Asghar [16] \\
\hline$N H-100$ & & & & \\
\hline $\begin{array}{c}\text { Pseudomonas sp. } \\
\text { BRp3 }\end{array}$ & siderophores & $\begin{array}{l}\text { Xanthomonas } \\
\text { campestris }\end{array}$ & $\begin{array}{c}\text { Rice bacterial } \\
\text { blight }\end{array}$ & Yasmin [1] \\
\hline
\end{tabular}

\section{Commercialization of PGPR based products}

\subsection{Bio power}

The first ever commercial product based on nitrogen fixing and growth hormone producing bacteria was launched by the name of BioPower in 1996 by the scientists at the National Institute for Biotechnology and Genetic Engineering, Faisalabad. BioPower made use of a diverse range of diazotrophic bacteria to improve growth of cereal and legume crops. BioPower was based on specific bacterial strains for specific leguminous and non leguminous crop systems. The use of BioPower resulted in a $20 \%$ increase in the yield of paddy, $15 \%$ of wheat and $60-80 \%$ increase in legumes with a saving of $50-100 \%$ chemical $\mathrm{N}$ fertilizer. BioPower was launched and marketed with the help of the public sector. 


\subsection{Humiphos and Biophos}

We have also patented the first ever substitute for phosphorus fertilizers in Pakistan by the trade names 'Humi-phos' and 'Bio-phos' in association with the AURIGA group of companies, Pakistan which has offered its services for establishing Asia's largest and Pakistan's first biofertilizer plant of 50 metric ton per day capacity in addition to its efficient marketing network. This product is based on improving the overall availability of phosphorus in soil and is not crop specific. The outcome of Humiphos and Biophos proved to be so effective that it gained an extraordinary appreciation from the farmers. In the crop seasons of winter and spring 2010-11 farmers clearly noticed improved germination, seedling vigour, healthy stand and increased yield along with partial phosphatic fertilizer saving. The performance of these products is changing the scenario of our agriculture. According to an estimate, there has been a positive impact of 6.5 billion rupees in Pakistan's economy in terms of yield increase and saving of phosphatic fertilizer. Humiphos and Biophos is an excellent example of academia - private sector linkage.

\section{Acknowledgements}

We acknowledge the efforts of all the members of Metabolomics and Genomics Lab/Pakistan Collection of Microbial Cells (PCMC) especially Dr. Zakira Naureen. We are also thankful to the Higher Education Commission (HEC) Pakistan and Pakistan Science Foundation (PSF) for providing funds in terms of various projects to conduct basic research that resulted in the formulation of the commercial product. We are especially thankful to Pakistan Science Foundation (PSF) for providing funds to present this work at the conference "Food and Environment, $21^{\text {st }}-23^{\text {rd }}$ June, 2011, New Forest, UK”.

\section{References}

[1] Yasmin, S. 2011. Characterization of growth promoting and bioantagonistic bacteria associated with rhizosphere of cotton and rice. $P h D$ dissertation, NIBGE/ Quaid-i-Azam University, Islamabad, Pakistan.

[2] Naureen, Z., Hameed, S., Yasmin S., Malik, K. A., and Hafeez, F. Y., Characterization and screening of bacteria from maize grown in Indonesian and Pakistani soils. Journal of Basic Microbiology, 45, pp. 447-459, 2005.

[3] Yasmin, S., Bakar, M.A.R., Malik, K. A. and Hafeez, F. Y., Isolation, characterization and beneficial effects of rice associated PGPRs from Zanzibar soils. Journal of Basic Microbiology, 44, pp 241-252, 2004.

[4] Hafeez, F. Y., Akkermans, A. D. L and Chaudhary, A. H., Morphology, physiology and Infectivity of two Frankia isolates An 1 and An 2 from root nodules of Alnus nitida. Plant and Soil. 78, pp 45-59, 1984.

[5] Hafeez, F. Y., Asad, S., Ahmad, T and Malik, K. A., Host specificity and characterization of fast growing rhizobia from Macroptilium 
atropurpureum cv. Siratro in Pakistan. Soil Biology and Biochemistry. 27(4/5), pp. 729-733, 1995.

[6] Hassan, Z., Detection and Quantification of Phytohormones and ACCDeaminase Activity in Rhizobium spp. PhD thesis submitted to $Q A U$, Islamabad, 2010.

[7] Hameed, S., Yasmin, S., Malik, K. A., Yusuf, Z and Hafeez, F. Y., Rhizobium, Bradyrhizobium and Agrobacterium strains isolated from cultivated legumes. Biology and Fertility of Soils, 39, pp 179-185, 2004.

[8] Ahmad M. Biochemical and Molecular basis of Phosphate and Zinc mobilization by PGPR in Rice. M.phil Dissertation. NIBGE/Quaid-i- Azam University, Islamabad. 2007.

[9] Hassan, M. N., Afghan, S and Hafeez, F. Y., Biological control of red rot in sugarcane by native pyoluteorin producing Pseudomonas putida strain NH50 under field conditions and its potential mode of actions. Pest Management. Science. DOI 10.1002/ps.2165, 2011.

[10] Hassan, M. N., Osborn, A. M and Hafeez, F. Y., () Biochemical and molecular characterization of surfactin producing Bacillus sp antagonistic to Colletotrichum falcatum causing red rot of sugarcane. African Journal of Microbiology Research 4(20), pp 2137-2142, 2010.

[11] Naureen, Z., Hafeez, F. Y and Roberts, M. R., Induction of systemic resistance against rice blast disease by PGPR isolated from the rhizosphere of rice In: "Microbial technologies for sustainable agriculture", Hafeez FY, KA Malik and Y Zafar (Ed) Crystal press, Islamabad, Pakistan p 269. ISBN: 978-969-8189-14-3, 2009.

[12] Naureen, Z., Adam, H. P., Hafeez, F. Y and Roberts, M. R., Identification of rice blast disease-suppressing bacterial strains from the rhizosphere of rice grown in Pakistan. Crop Protection 28, pp 1052-1060, 2009.

[13] Tariq, M., Sumera, Y and Hafeez, F. Y., Biological control of potato black scurf by rhizosphere associated bacteria. Brazilian Journal of Microbiology 41, pp 439-451, 2010.

[14] Gull, M., Biological control of pathogenic infection through plant growth promoting rhizobacteria (PGPR), PhD dissertation, NIBGE/ Quaid-i-Azam University, Islamabad -Pakistan. 2008.

[15] Mehmood, M. A., Xiao, X., Hafeez, F. Y., Gai, Y and Wang, F., Purification and characterization of a chitinase from Serratia proteamaculans. World Journal of Microbiology and Biotechnology, 25, pp 1955-1961, 2009.

[16] Asghar, J., Bioantagonist activity of plant growth promoting rhizobacteria (PGPR) against Meloidogyne javanica for the control of root knot disease of tomatoes. PhD dissertation submitted University of Agriculture Faisalabad-Pakistan. 2008 